УДК 656.2.001.47

\title{
КУЛЬТУРА ПРАЦІ ТА ПРАЦЕВЛАШТУВАННЯ МОЛОДІ
}

\author{
Гриценко Н.В., к.е.н., доцент (УкрДУЗТ)
}

У статті детально обтрунтовується необхідність перегляду існуючих підходів до культури праці та працевлаштування молоді в Україні. Розглянуті проблеми адаптації молоді та виділені чинники. Встановлено, щзо внутрішні чинники обумовлені необхідністю підвищення ефективності організації трудових відносин у великих компаніях та корпорачіях. Особлива увага приділена проблемам формування дієвої корпоративної стратегї та трудової адаптації, а також внутрішньої організаційної політики.

Ключові слова: корпоративна культура праці, організаційна культура, корпоративна ідентичність, трудова адаптація молоді, людський капітал, ринок праці, економічна соціологія.

\section{КУЛЬТУРА ТРУДА И ТРУДОУСТРОЙСТВА МОЛОДЕЖИ}

\section{Гриценко Н.В., к.э.н., доцент (УкрГУЖТ)}

В статье подробно обосновывается необходимость пересмотра существующих подходов к культуре труда и трудоустройства молодежи в Украине. Рассмотрень проблемы адаптации молодежи и выделены факторы. Установлено, что внутренние факторы обусловлены необходимостью повытения эффективности организации трудовых отношений в крупных компаниях и корпорациях. Особое внимание уделено проблемам формирования действенной корпоративной стратегии и трудовой адаптации, а также внутренней организациионной политики.

Ключевые слова: корпоративная культура труда, организационная культура, корпоративная идентичность, трудовая адаптация молодежи, человеческий капитал, рынок труда, экономическая социология.

\section{CULTURE OF LABOR AND EMPLOYMENT OF YOUTH}

\author{
Gritsenko N.V., Candidate of Economic Sciences, Associate Professor \\ (Ukrainian State University of Railway Transport)
}

The article deals with the problems of labor adaptation of youth in organizations and enterprises, and the influence on this process of transformation of the corporate culture of labor. The main problems of labor adaptation of young people in the modern conditions of development of labor markets are analyzed theoretically. The problem of youth employment is considered, which today is one of the priority tasks of state development. Ensuring a satisfactory level of youth employment today is one of the priority tasks of the state's development. After all, young people are the most active part of the able-bodied population. Only taking into account the dynamics of the level of its employment it is possible to develop socio-economic forecasts of the country's development for the long-term perspective. The problem of youth employment is of interest to many scholars in the world. However, in Ukraine, it is updated on average every five years. This is due to the need for government 
programs to support and promote the development of this population.

Young people are more exposed to both external and internal influences on the situation with ensuring its employment as a more productive part of the population. In the process of finding a job, young unemployed people face certain psychological difficulties. Their cause is the lack of internal readiness for active involvement, inability to change previous settings, and motivation for behavior in new market conditions. Unresolved problems of youth employment lead to rising unemployment and lower living standards; the spread of passive (dependency), unregulated (shadow occupancy) and destructive (criminal) behavior patterns; inducing external labor migration; cause psychological changes (loss of motivation to work, change in the structure of value orientations and the fall in the prestige of legal employment].

The state still can not solve all problems on its own. Therefore, all public associations should work on these issues and problems and look for effective solutions to them, and only by creating a favorable business environment in Ukraine we will solve many important problems, including for the development of economic activity of youth, and the realization of their labor potential. Consequently, the main measures to be taken to reduce youth unemployment must be campaigning and educational work.

Key words: corporate culture of labor, organizational culture, corporate identity, labor adaptation of youth, human capital, labor market, economic sociology.

Постановка завдання дослідження. На сьогодні зв'язок між проблемами культури праці і працевлаштуванням поки що недостатньо усвідомлюється і враховується як спеціалістами 3 організації праці, так і культурологами. Проте фактично форми i способи організації праці в будь-якій галузі являє собою культурні сценарії трудової діяльності, які також впливають на працевлаштування молоді [6]. В Україні проблема працевлаштування $\epsilon$ дуже гострою, особливо для молоді. Це i актуалізує необхідність дослідження проблеми працевлаштування молоді та культури праці.

Метою даного дослідження $\epsilon$ вивчення теоретичного аспекту впливу організаційної культури на можливості і перспективи адаптації молоді до існуючої системи внутрішньо-корпоративних формальних та неформальних соціальнотрудових комунікацій, які інтегруються в корпоративну культуру праці.

Аналіз досліджень і публікацій. Дослідженням культури праці займається велика кількість науковців, таких як
Лисенко Л.І., Максимов Б.В., Маригодов В.К. [5], Щотова Ю.М. [6]. Однак дане питання сьогодні тільки набирає оберти, так як, невід'ємно пов'язане 3 економічними та політичними змінами в державі, чим більше викликає інтерес наукових діячів цієї галузі.

Виклад основного матеріалу. В сучасній світовій економіці ринок праці країни відчуває вплив загальносвітових негативних тенденцій, пов'язаних 3 наслідками глобальної фінансовоекономічної кризи, а також довгострокових тенденцій, таких як структурна криза зайнятості молоді. Підвищується рівень глобального безробіття.

Зараз, відбувається послідовне зниження рівня участі молоді в глобальній робочій силі при паралельному зменшенні частки зайнятої молоді від загальної чисельності молодого населення України.

За статистичними даними Державної служби України, офіційний рівень безробіття серед молоді з кожним роком стає все вище (рис.1) [1]. 


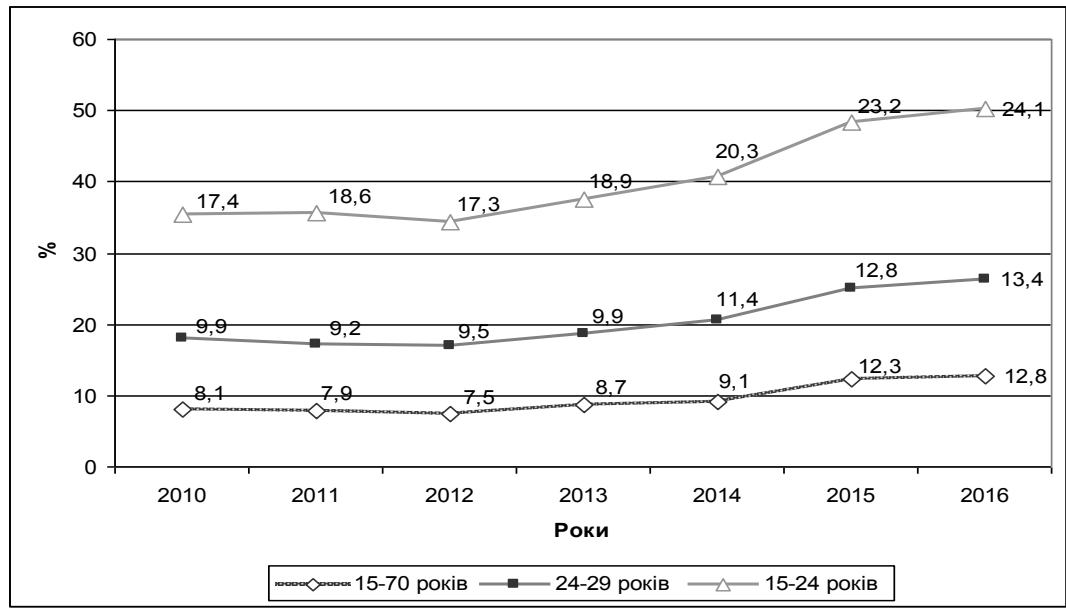

Рис. 1. Загальний рівень безробіття серед населення Украӥни, \%

На це впливає велика кількість чинників, а глобальна фінансовоекономічна криза лише посилила раніше сформовані негативні структурні зміни зайнятості серед молоді $[1,2]$.

Головною причиною зростання безробіття стало падіння економіки та відповідне зниження фінансових результатів діяльності вітчизняних підприємств. Частина підприємств збанкрутіла, а деякі, щоб запобігти втратам, почали знижувати рівень своїх витрат та оптимізовувати штат працівників. Ще одним спонукаючим фактором стало підвищення мінімальної заробітної плати до 3200 грн. Це змусило підприємців, які не в змозі збільшити свій фонд оплати праці, перевести працівників на неповний робочий день або взагалі на неформальну зайнятість. Також підняття рівня мінімальної заробітної плати вплинуло на діяльність малого бізнесу, що використовує спрощену систему оподаткування.

Наслідком цих змін стало погіршення становища молоді на ринку праці, оскільки в Україні:

- зменшилися державні інвестиції в створення нових робочих місць для молоді;

- обмежився доступ до якісної освіти, це, насамперед, пов'язане 3 високою оплатою за навчання, посиленням диференціації за рівнем доходів населення країни;

- знизилася якість вже наявних робочих місць для молодих працівників (збільшення найомної праці, зниження соціальної захищеності працюючих, скорочення рівеня участі молодих працівників в діяльності профспілок та економіко-правової захищеності, збільшення зайнятості молоді у неформальному секторі) $[4,5]$.

У цих умовах проблеми трудової адаптації молоді набуває важливого значення для відтворення і підвищення якості робочої сили в Україні.

Внутрішні чинники обумовлені необхідністю підвищення ефективності організації трудових відносин у великих сучасних компаніях i використання їx головної конкурентної переваги в глобальній економіці інтелектуального (людського) капіталу.

Українська сучасна внутрішньокорпоративна організація праці відчуває на собі істотний тиск, обумовлений наявністю латентних трудових конфліктів. Причини цих трудових конфліктів полягають у звуженні рівності можливостей різних поколінь співробітників компаній в занятті якісних робочих місць (висока оплата, хороші умови праці та трудовий клімат). Мало які організації сьогодні надають широкі можливості для вертикальної трудової мобільності молоді, оскільки прийнято вважати, що конкурентоспроможність організації залежить переважно від досвіду 
працівників різних рівнів. Молоді працівники часто не мають такого досвіду. Однак, важливим елементом інтелектуального капіталу $\epsilon$ не тільки досвід співробітників, але й їх креативність, як прагнення до самореалізації у праці за допомогою активної участі в економічно ефективної інноваційної діяльності (різного характеру i спрямованості) на благо організації. Подібну креативність виявляють, як правило, саме молоді працівники, які прагнуть стати професіоналами в своїй справі, оскільки для них подібна стратегія трудової адаптації - єдиний спосіб порівняно швидкого просування вгору по кар'єрних сходах та підвищення свого соціального статусу.

Вивчення впливу внутрішніх та зовнішніх чинників, що впливають на ефективність трудової адаптації молоді, $\epsilon$ важливою частиною досліджень можливостей управління організаційною культурою праці. Оскільки рішення цих проблем багато в чому обумовлено саме ефективністю такого управління.

Сучасне становище більшості українських організацій 3 традиційним укладом організаційної культури характеризується зниженням частки зайнятих молодих фахівців. Утворилася помітна тенденція падіння зайнятості молодих працівників у виробничій сфері і різке збільшення в сфері послуг. Випускники ВУЗів не прагнуть влаштовуватися на роботу за своєю спеціальністю, оскільки є незатребуваними на ринку праці, або ж їхня праця $\epsilon$ низькооплачуваною i без перспективи зростання. Нове покоління працівників виявляється переважно поза процесами соціально-економічних перетворень, не може знайти своє місце в загальній i приватній структурі зайнятості, а значить не здатне повністю реалізувати себе [5]. При тому, що зайнятість молодих фахівців не збільшується, а швидкість зміни робочого місця збільшилася за останнє десятиліття в кілька разів. Якість вибору робочого місця катастрофічно знизився. Дана ситуація ускладнюється думкою, що отримана вища освіта не гарантує майбутнє отримання бажаної професії. Більш ніж у половини працюючих студентів (понад 55\%) робота не відповідає їх навчальній спеціалізації, що впливає на вибір їх майбутнього робочого місця. Багато молодих фахівців технічних спеціальностей в подальшому через необхідність пошуку прийнятного місця роботи знаходять його для себе в компаніях сфери послуг, йдуть в торгівлю чи успішно працевлаштовуються в зарубіжних корпораціях.

Це пояснюється загальним положенням економіки i ринку праці в Україні. Зниженням виробної потужності держави, закриттям великої кількості заводів та фабрик, зниженням виробництва продукції, збитком сільськогосподарської діяльності i т.д. Якщо розглянути приватний бізнес, то тут так само $\epsilon$ проблеми під час працевлаштування молоді. Основні критерії, за якими молоді здобувачі не потрапляють на привабливі i престижні посади у великих приватних компаніях - стаж i досвід роботи. Безумовно, в останне десятиліття 3 розвитком мережі Інтернет і розширенням числа його користувачів пошук роботи молодими людьми значно полегшився. Однак, якщо звернути увагу на спеціалізовані розділи різних сайтів 3 пропозицією робочих місць для молодих спеціалістів без досвіду роботи, то можна виявити, що вибір для них $\epsilon$ вельми не великим. Крім чого наявні пропозиції для молоді без досвіду трудової діяльності за фахом залишаються вкрай примітивними. Основним критерієм вибору для роботодавців є все ж досвід роботи.

Якщо молодому професіоналу все ж вдалося отримати роботу у великій успішної української організації, то на його шляху виникає наступна перешкода відсутність чіткої корпоративної стратегії та інфраструктури трудової адаптації. Проблемність полягає як в рекрутингу молодих фахівців, так й в їх адаптації та 
утриманні на робочому місці. При виборі конкретної моделі адаптивної поведінки менеджмент корпорацій керується різними критеріями: затратністю, часом, мінімізацією адаптивного ризику, максимізацією адаптивного успіху.

Наступною проблемою $є$ відсутність реально працюючої внутрішньої політики організації, спрямованої на підбір, навчання i розвиток персоналу. Більшість великих українських організацій можуть собі дозволити утримувати великий штат департаменту 3 управління персоналом. Однак, фактично, багато проектів i програм, спрямованих на розвиток i адаптацію молоді в організації, в реальності не працюють, а існують лише на папері. Таким чином трудова адаптація молоді $\epsilon$ перспективним завданням HR-брендингу крупних українських організацій, та поки що далеким від ефективних шляхів його вирішення в нинішній ситуації на ринку праці.

Інтеграція та утримання молодих фахівців може відбуватися завдяки проведенню політики планування кар'єри кожного співробітника, створення спеціального кадрового резерву з молодих фахівців. Адаптація молоді - це не тільки інтеграція в корпоративну культуру, колектив 3 певним укладом і правилами поведінки, необхідно також пам'ятати про інтеграцію в процеси прийняття рішень, планування подальших короткострокових i довгострокових стратегій, тобто про участь в управлінні організацією. При адаптації у молодих фахівців необхідно розвивати почуття причетності у всьому. Лише тоді можна говорити про ефективну їх адаптацію в організації.

Політика створення кадрового резерву з молодих фахівців свідчить про готовність організації до реальних внутрішніх інвестицій в розвиток людського капіталу. Економічно успішні підприємства підходять до цього комплексно, зміцнюють кадровий склад всього підприємства, але, на жаль для них, часто забуваючи про створення специфічних умов для розвитку молоді (отримання нових знань, навчання за іншими спеціальностями, підвищення кваліфікації, придбання додаткових компетенцій).

Також, важливу роль для молодих фахівців при адаптації в організації має система винагород. Позитивні винагороди того чи іншого варіанту адаптаційної поведінки мають місце тоді, коли соціальне середовище «у відповідь» дарує суб'єкту адаптації гідні нагороди i заохочення, збільшуючи тим самим ймовірність повторення даного вчинку або варіанти адаптивної поведінки в майбутньому [2]. Однак щодо питання заробітної плати та кар'єрного зростання молодих фахівців існує й інша позиція. Нове покоління у віці від 18 до 25 років відрізняється невиправданою амбітністю. Випускники ВУЗів, маючи престижні спеціальності, стикаються з проблемою невідповідності їх амбіцій реальним можливостям регіональних і національних ринків праці. Ринки праці взагалі не сприйнятливі до подібних амбіцій, а громадська думка, найчастіше, лише їх заохочує. Наприклад, в Україні, на відміну від європейських країн, в суспільстві немає сприйняття принципів урахування терміну служби в організації для кар'єрного зростання. У Свропі, щоб зрости до посади старшого фахівця необхідно обов'язково відпрацювати на посаді молодшого не менше двох, а то й більше, років.

Ефективність трудової адаптації молоді в чималому ступені залежить також від соціально-психологічного клімату в колективі, від відчуття соціальної захищеності у молодих фахівців. Однак в багатьох великих компаніях керівництво поки не бачить необхідності в реалізації спеціальних внутрішньо-корпоративних соціальних програм підтримки молодих фахівців, вважаючи за краще робити ставку на фахівців 3 великим досвідом і терміном роботи в організації. В соціальному плані молоді фахівці більш вразливі своїх старших колег. Дана ситуація складається i 
в тому числі і тому, що молодь відмовляється від захисту своїх трудових прав за допомогою вступу в колективнодоговірні відносини і активної участі в діяльності профспілок. Колективнодоговірні відносини поки не стали в багатьох українських організаціях важливим елементом організаційної культури, фактором, що впливає на формування корпоративної ідентичності. А в тих організаціях, де $\epsilon$ профспілки, в структурі колективно-договірних відносин немає спеціальних положень про працю молодих фахівцях та їх соціальний захист [6]. Рішення проблем підвищення соціальної захищеності молодих працівників може позитивно позначитися i на підвищенні ефективності їх трудової адаптації в сучасних несприятливих умовах трансформації ринків праці.

Необхідно збалансувати процес «виховання» молодого покоління фахівців. Саме, молоді фахівці можуть забезпечити зростання продуктивності праці i якості робочої сили. Проблему плинності кадрів на великих українських підприємствах i проблему утримання молодих співробітників на робочому місці можна вирішити, хоча б частково, шляхом створення гнучких моделей підвищення кваліфікації молодих співробітників (враховуючи як інтереси організації, так і кар'єрні амбіції молодих фахівців). На жаль, на сьогоднішній день, багато українських підприємств були змушені відмовитися від відомчих вищих навчальних закладів, які готували їм якісних фахівців. Хоча дана система дозволяла, при незначній фінансовій підтримці навчальних закладів, отримувати необхідні їм професійно підготовлені молоді кадри. На мій погляд, необхідно відновити і розвивати даний взаємозв’язок «підприємство - вищих навчальних закладів», для того щоб підприємство або організація спочатку змогла створювати і планувати кадри «для себе» навіть 3 особливо вузькими спеціалізаціями (профілізація), не кажучи вже про підготовку фахівців широкого профілю.

Декларації про необхідність омолодження кадрів для великих українських організацій повинні стати невід'ємною частиною корпоративної стратегії інноваційного розвитку. Можливі шляхи вирішення цієї проблеми не нові:

- проведення заходів 3 пошуку талановитої молоді та створення позитивного іміджу робочого місця;

- тимчасовий найм студентів за фахом;

аспірантами;

- керівництво дипломниками i

- організація студентської виробничої практики;

- укладання тристоронніх договорів (студент - ВНЗ - підприємство);

- співпраця з центрами зайнятості.

Ось далеко не всі ці заходи підтримуються на ділі керівництвом великих організацій та самою державою.

Важливим аспектом $є$ наявність державної інноваційно-орієнтованої промислової політики, частиною якої $\epsilon$ виховання нового покоління фахівців, що приходить на ринок праці молодих працівників. Маючи в своєму розпорядженні колосальний вплив на великий бізнес, держава може сприяти формуванню та розвитку ефективної інфраструктури трудової адаптації молоді. Прикладом формування подібної ефективної інфраструктури трудової адаптації молоді цілком могли б стати і великі державні підприємства і організації.

Висновок. 3 вище наведеного видно, що для утримання і адаптації молоді у великих організаціях можна активно i ефективно задіяти і традиційні канали. Однак поки українські підприємства залишаються перед вибором приймати готових досвідчених фахівців або самим вирощувати і адаптувати свої молоді кадри. У пресі активно анонсується реструктуризація і об'єднання вищих навчальних закладів. На жаль, рідкісне інтерв'ю або новини в ЗМІ про ВНЗ зачіпає питання успішності майбутніх випускників 
певного вищого навчального закладу на ринку праці. У мережі Інтернет можна знайти велику кількість статей і публікацій, в тому числі і молодих вчених, проблеми працевлаштування та адаптації молоді. Однак, складно знайти інформацію про успішні корпоративні програми підтримки молоді.

Розвиток ефективних корпоративних систем управління організаційної культурою може стати міцною основою для трудової адаптації молодих фахівців в сучасних складних умовах трансформації глобальних i локальних ринків праці, а також істотно вплинути на зростання інноваційної складової економічного розвитку великих корпорацій, організацій, підприємств та бізнесу.

\section{ПЕРЕЛІК ВИКОРИСТАНИХ ДЖЕРЕЛ}

1. Про сприяння соціальному становленню та розвитку молоді України: Закон України Оф. сайт Державної служби статистики України [Електронний ресурс]. - Режим доступу: http://www.rada.gov.ua

2. Гриценко Н.В. Перспективы альтернативного железнодорожного

транспорта современным руководителем / Н.В. Гриценко // «Ученые записи»-Scientifics works, Азербайджанского Технического Университета. Баку:-2014. - №1.- С. 129132.

3. Гриценко Н.В. Теоретический поход к проблеме мотивации персоналом на железнодорожном транспорте / Н.В. Гриценко // Зб. наук. праць. Технік. прогрес і ефект. виробництва -Харків: ХТУ «ХПІ». 2016. - №27 (1199). - C. 38-43.

4. Гриценко Н.В. Діяльність менеджера в сфері управління людськими ресурсами / Н.В. Гриценко // Вісник економіки транспорту і промисловості. 2016. - №54. - С. 345 - 349.

5. Лисенко Л.І. Ринок праці. Техніка пошуку роботи : навч. посіб. для студ. вищ. навч. закл. / Л.І. Лисенко, Б.В. Максимов, В.К. Маригодов. - К.: Вид. дім «Професіонал», 2004. - 311 с.

6. Щотова Ю.М. Правове регулювання працевлаштування молоді в Україні / Ю.М. Щотова; Академія праці і соціальних відносин Федерації професійних спілок України. - К.: АПСВ, 2007. $-192 \mathrm{c}$.

УДК 658.14 (477)

\title{
ДОСЛІДЖЕННЯ МОДЕЛЕЙ СОЦІАЛЬНОЇ ВІДПОВІДАЛЬНОСТІ У БІЗНЕСОВОМУ СЕРЕДОВИЩІ ТА МОЖЛИВОСТЕЙ ЇХ ЗАСТОСУВАННЯ В УКРАЇНI
}

\author{
Панченко Н.Г., к.е.н., доцент (УкрДУЗТ)
}

\begin{abstract}
Визначено, щуо сочіальну відповідальність бізнесу можна визначити як добровільне зобов'язання бізнес-організащій проводити таку політику, приймати такі рімення, розвивати такі напрямки діяльності, які є бажаними з точки зору цілей та цінностей суспільства. Зроблено висновок, щуо особливість СВБ в Україні - це ігнорування українськими компаніями базового рівня сочіальної відповідальності $i$ іï реалізачія на другому і третьому рівнях. В той же час, розширення сфери СВБ за рамки базового рівня $i$, тим більше за межі корпорації, зустрічає протест з боку ії працівників. Бізнес-структури при обранні напрямків сочіальних інвестицій надають перевагу тим з
\end{abstract}

(C) Панченко Н.Г.

Вісник економіки транспорту і промисловості № 60, 2017 